\title{
Verandering naar gezond gedrag, hoe doen we dat?
}

\author{
K.I. Proper • W. van Mechelen
}

De gezondheid van de Nederlander ontwikkelt zich minder goed dan die van andere Europeanen. Ongezond gedrag is de belangrijkste oorzaak van de ongunstige trends in gezondheid. Een aanzienlijk deel van de jaarlijkse sterfte hangt samen met dit gedrag: roken (ca. $15 \%)$, te weinig bewegen $(6 \%)$, ernstig overgewicht $(6 \%)$, te weinig groente en fruit $(5 \%)$ en te veel verzadigd vet $(5 \%)$. Dit zijn enkele conclusies uit 'Gezondheid op koers?' de derde Volksgezondheid Toekomstverkenning van het RIVM. ${ }^{1}$ Verandering van gedrag lijkt dus een aangewezen manier om de gezondheid te bevorderen. Maar hoe kunnen we gedragsverandering bewerkstelligen? Hiertoe hebben we inzicht nodig in de factoren die ons gedrag bepalen en inzicht in de wijze waarop we van gedrag veranderen. In de afgelopen decennia zijn diverse modellen ontwikkeld om gezondheidsgerelateerd gedrag te verklaren. Deze modellen bevatten in het algemeen drie clusters van determinanten die samen de motivatie van een persoon bepalen om een bepaald gedrag uit te voeren:

1. kennis en attitude;

2. sociale invloed; en

3. eigen-effectiviteitsverwachting en barrières.

Attitude wil zeggen de houding van een persoon ten aanzien van een bepaald gedrag en wordt over het algemeen gevormd door het afwegen van de voor- en nadelen die iemand heeft ten aanzien van dat gedrag. Het tweede aspect, sociale invloed, heeft betrekking op sociale normen, het waargenomen gedrag van anderen en de ervaren steun voor het gewenste gedrag. En tot slot, eigen effectiviteitsverwachting. Dit wordt gevormd door de inschatting van een persoon om een bepaald gedrag uit te kunnen voeren, de inschatting van een persoon van de mate waarin hij zich in staat acht om sociale druk te weerstaan of te benutten, en door de inschatting om het gewenste gedrag te kunnen blijven vertonen in situaties van spanning. Een persoon met een positieve attitude, veel sociale steun en een hoge eigen-effectiviteitsverwachting zal dus eerder in staat zijn om het gedrag te veranderen ten opzichte van personen met een negatieve attitude, weinig sociale steun en een lage eigeneffectiviteitsverwachting.

Naast deze persoonlijke determinanten is er tegenwoordig veel aandacht voor de (sociale en fysieke) omgeving als belangrijke determinant van ons gedrag. Het wordt ons namelijk tegenwoordig steeds makkelijker gemaakt om ongezond gedrag te vertonen. Verandering van de omgeving, zoals het aantrekkelijk en duidelijk zichtbaar maken van de trap, het verwijderen van roltrappen of het 'verstoppen' van de lift zijn voorbeelden van omgevingsveranderingen die het ons daarentegen juist makkelijker maken om een gezonde keuze te maken en actief te zijn. Voor het ontmoedigen van ongezonde voeding kan bijvoorbeeld gedacht worden aan het labellen van voedingsproducten in de (bedrijfs)kantine of het vervangen van de snoepautomaat door een fruitautomaat, of het verwijderen van de frisdrank uit de automaten.

Een veelgebruikt model dat zich richt op de verandering van gezondheidsgedrag is het transtheoretisch model (TTM) waarin de 'fasen van gedragsverandering' een kernconcept vormen. ${ }^{2}$ Het TTM gaat er vanuit dat mensen een aantal fasen doorlopen bij het veranderen van hun gezondheidsgedrag. Deze fasen zijn gebaseerd op het huidige gedrag en de motivatie om dit gedrag in positieve zin te veranderen en zijn:

1. precontemplatie;

2. contemplatie;

3. preparatie; 
4. actie;

5. behoud; en

6. terugval.

In de eerste fase (precontemplatie) overweegt de persoon geen gedragsverandering. In de contemplatiefase echter, overweegt hij binnen zes maanden zijn gedrag daadwerkelijk te veranderen en in de preparatiefase is de persoon al met kleine veranderingen begonnen of overweegt hij binnen een maand te veranderen van gedrag. In de actiefase is het gedrag in minder dan zes maanden geleden veranderd. Deze fase kan gevolgd worden door behoud of terugval in het oude en ongezonde gedrag. Een interventie die gebaseerd is op het TTM wordt ingevuld op basis van de fase van gedragsverandering waarin iemand zich bevindt. Het belang voor een interventie van de determinanten verschilt per motivationele fase. Als gevolg daarvan is het doel en de inhoud van de interventie verschillend en afhankelijk van de fase van gedragsverandering van de persoon. Zo zal bij een persoon in de pre- contemplatiefase het vergroten van kennis over het onderwerp een belangrijk aandachtspunt vormen, terwijl bij iemand in de contemplatie of preparatiefase het opstellen van een concreet gedragsveranderingplan gewenst is. En bij iemand in de actiefase zal er zorg moeten zijn voor het voorkomen van terugval, opdat het gezonde gedrag behouden blijft.

Uit diverse onderzoeken is gebleken dat een dergelijke aanpak effectief is en bijvoorbeeld goed uitvoerbaar is in de huisartsenpraktijk. ${ }^{3}{ }^{5}$ Het is denkbaar dat dergelijke interventies door de bedrijfsarts uitvoerbaar en effectief zijn. De bedrijfsarts kan op die manier een belangrijke bijdrage leveren aan de verandering of het behoud van gezond gedrag.

\section{Literatuur}

Oers JAM van. Gezondheid op Koers? Volksgezondheid Toekomst Verkenning 2002. Bilthoven: RIVM Rapport 270551001, 2002.

Prochaska JO, DiClemente CC. Stages and processes of self change of smoking: Toward an integrative model of change. J Consult Clin Psychol 1983; 51: 390-395.

Long BJ, Calfas KJ, Wooten W, et al. A multisite field test of the acceptability of physical activity counseling in primary care: project PACE. Am J Prev Med 1996; 12: 73-81.

Calfas KJ, Long BJ, Sallis JF, et al. A controlled trial of physician counseling to promote the adoption of physical activity. Prev Med 1996; 25: 225-233.

Sluijs EMF van. Effectiveness of physical activity pro-motion: the case of general practice. Wageningen: Ponsen \& Van Looijen BV, 2004. 